\title{
A kontraszelekció és a negatív szelekció problematikája és típusai*
}

\author{
Csorba László
}

Viszonylag sok esetben vannak olyan szelekciós kritériumok a mindennapokban, melyek érvényesülése a gazdaságban nyilvánvalóan nem támogatja a fejlődést, még rövid távon sem. Ugyanakkor a kontraszelekció jelensége valójában nagyon ritkán üti csak fel a fejét, hiszen annak egyformán előfeltétele a nagymértékü rejtett információtömeg, illetve az érintettek teljes jóhiszemüsége. A negativ szelekció ehhez képest szükségszerübben gyakoribb eset. A releváns információk ilyenkor a felek rendelkezésére állnak. Ugyanakkor tudatosan visszaél erőfölényével, illetve hatalmával az azzal rendelkező egyén vagy csoport. Méghozzá pontosan azok hátrányára, akik aktuálisan leginkább megfelelnek a fennálló szelekciós követelményeknek, ennek ellenére a megfelelö alkupozíció, illetve érdekérvényesítő képesség hiányában kiszolgáltatottak. A birtokolt erőfölénnyel, hatalommal azonban „rendeltetésszerüen” is lehet élni, ami révén pozitiv - a fejlődést jó eséllyel elősegítő - szelekciót lehet megvalósítani.

Journal of Economic Literature (JEL) kódok: D81, D82, D92, E32, L15

Kulcsszavak: gazdasági evolúció, gazdasági szelekció, kontraszelekció, negatív szelekció, piaci struktúra, stakeholder-elmélet

\section{Bevezetés}

A népmesékben megszokott befejezés az, hogy a jó elnyeri jutalmát. $A z$, hogy a hétköznapokban ez nem mindig van vagy lehet így, természetesnek tűnik, hiszen a modern piacgazdaságokban sincs minden erőfeszítés sikerre ítélve. Az már figyelemreméltóbb, hogy Kelet- és Közép-Európában többnyire nem érezzük túlzónak a „Mindig azt a lovat ütik, amelyik húz” szólásmondás üzenetét. Vörösmarty Mihály az írta a Szózat című versében: „S elhulltanak legjobbjaink a hosszú harc alatt”. Valóban, sokat elmond egy közösségről, egy szervezetről, egy csoportról, vagy egy vállalatról, hogy miként bánik a legjobbjaival. Egy valamire való hadvezér, vagy akár egy labdarúgóedző is tudja, hogy a legjobbakat óvni, kímélni és támogatni is kell annak érdekében, hogy minél tovább, illetve minél jobban szolgálhassák a közösségük,

* A jelen kiadványban megjelenő írások a szerzők nézeteit tartalmazzák, ami nem feltétlenül egyezik a Magyar Nemzeti Bank hivatalos álláspontjával.

Csorba László az Eszterházy Károly Egyetem Gazdaságtudományi Intézetének adjunktusa.

E-mail: csorba.laszlo@uni-eszterhazy.hu

A magyar nyelvű kézirat első változata 2018. szeptember 24-én érkezett szerkesztőségünkbe.

DOI: http://doi.org/10.25201/HSZ.18.2.88116 
s végső soron a vezetők érdekeit is. Tudják, hogy a legjobbak létének kockáztatásával, esetleges elvesztésükkel a közösség túlélése válhat kérdésessé. A mindennapokban ugyanakkor sok esetben relatíve hátrány éri a legjobb dolgozókat, vezetőket, a legjobb ügyfeleket, vagy akár kiemelkedő teljesítményű vállalatokat, sőt egész iparágakat is. A gazdasági szereplők jellemzően nem közvetlenül személyükben, jogilag, vagy fizikailag szenvedik el a hátrányokat, hanem az általuk elóállított termékek, szolgáltatások, a folytatott tevékenység, általában a megvalósított tevékenység alulértékelése révén. Ez az alulértékelés szervezeten belül, illetve kívül is megvalósulhat, s ez sugárzódik majd vissza (Schumpeter /1934/1980) valamennyi, az adott érték létrehozásában közreműködő szereplőre. Széchenyi István erről a következőket írta: „A magyar gazda nem viheti mezeit a lehetö legmagasb virágzásra. (...) A limitácziók pedig kivált a hús limitácziója annak oka, hogy a mezei gazdaságunk egy sarkalatos alapköve béna sígy egy lábbal a levegöben áll. A hús megállapított ára minden derekas hizlalást haszontalanná tesz; hol pedig a hízlalás haszontalan, ott a gazdaságnak sarkalatos talpköve hiányzik. A jó hús nem drágább, mint a rossz, s így mért törekedne a gazda jobb húst elöállitani?" (Széchenyi /1830/ 1903:58-59). Úgy tűnik, hogy a hazai gazdasági szereplők - szinte már hagyományosan - többsége nem érzékeli kellőképpen annak a komolyságát, hogy a számukra legmegfelelőbb magas minőséget - bármilyen területen is szükséges az számukra - megfelelő módon értékelni, honorálni kell ahhoz, hogy az érintett szereplők releváns erőfeszítései hosszabb távon is kifejthessék kedvező hatásukat. Az ehhez szükséges tudatossághoz kíván segítséget nyújtani ez a tanulmány.

\section{A gazdasági evolúció alaplogikája}

Darwin biológiai evolúcióra vonatkozó elmélete többféle tudományra, így a közgazdaságtanra is nagy hatást gyakorolt. Az idea, hogy a szüntelenül létrejövő variánsokból a szelekció rostázó hatása révén egy, a környezetével nagyfokú összhangot elérni képes populáció jöhet létre, számos közgazdász fantáziáját megmozgatta. Az evolúciós közgazdaságtan egyik alapítójának tekintett Thorstein Veblen (1899:125) szerint "az ember élete a társadalomban csakúgy, mint más fajok élete, a létezésért folyó harc, a szelektiv alkalmazkodás folyamata. Az emberi intézmények és az emberi jellem múlt- és jelenbeli fejlődését általában a legmegfelelöbb gondolkodásmódok kiválasztódásának tulajdonítjuk, valamint annak, hogy az egyének kénytelenek ahhoz a környezethez alkalmazkodni, amely állandóan változik a közösség fejlödésével és az emberek életét körülvevő intézményekkel"1.

Sokáig látszólag egyértelmúnek tűnt az analógia a biológiai egyedek, illetve a gazdasági szereplők, a populáció és a nemzetgazdaság, iparág vagy piac között. Különösen abban a speciális esetben, amikor a gazdasági szereplő, illetve a populáció

\footnotetext{
${ }^{1}$ Veblen (1972: 180) Berényi Gábor fordítása.
} 
nagyfokú alkalmazkodóképességét a gazdasági fejlődéssel azonosították. Kotosz (2002) is rámutatott arra a tényre, hogy az evolúciós közgazdaságtanra - hasonlóan a közgazdaságtan számos ágához, kiváltképp, melyek nem tartoznak az ún. főáramba - nincs is pontos, általánosan elfogadott meghatározás. Beinhocker (2006) szerint maga a gazdasági evolúció, annak alaplogikája játékelméleti terminológiával egy „gyerekjáték”, ebben nincs és nem is lehet különbség a téma különböző területeit kutatók, elemzők között. Adott ugyanis egy sokaság, egy populáció, amelynek legyen - még vagy már - legalább két tagja. A populáció tagjai között legyen több-kevesebb különbség vagy az adottságok, vagy a folytatott tevékenység tekintetében. Azaz legyenek variánsok. A szelekció révén bizonyos következmények kapcsolódnak az egyes variánsokhoz attól függően, hogy milyen mértékű a megfelelőségük az éppen aktuális szelekciós követelmények tekintetében. Lehetséges, hogy az egymástól való eltérésnek - hogy ki melyik variáns - éppen nincs jelentősége, de jellemzően a variánsok eltérő következményekkel szembesülhetnek. Az inkább előnyös következmények javítják az adott variáns túlélési esélyeit, illetve túlélési kondícióit, az összességében hátrányos következmények pedig éppen ellenkezőleg. Beinhocker (2006) szerint a gazdasági evolúció abban más, mint a biológiai, hogy rendkívül nagy a tudatosság szerepe mind a variánsok létrejöttében, mind a szelekciós követelmények terén, ezáltal az ember biológiai adottságai sokkal kisebb súllyal eshetnek latba. Harford (2011) ki is emeli, hogy a biológiai evolúcióban nincs és nem is lehet előrelátás, tervezés, csak a próbáknak való megfelelés különböző szintjei. Kizárólag az aktuális variánsok és az aktuális szelekciós követelmények léteznek. Ugyanakkor a gazdasági evolúcióban az ember próbál - több-kevesebb sikerrel - előretekinteni, tervezni, a szelekció során előnyre szert tenni akár hosszabb távú befektetések, áldozatok révén is. Amiért mégis olyan sokszínű maga az evolúciós közgazdaságtan Beinhocker (2006) szerint, annak az oka az, hogy különböző koncepciók léteznek a variánsok, a szelekciós követelmények létrejöttére, a szelekció menetére vagy a gének mibenlétére, kifejeződésére és átörökítésére, illetve a sikeres minta terjedésére, továbbá - egyebek mellett - a gazdasági fejlődés és a gazdasági evolúció kapcsolatára vonatkozóan.

A XX. század egyik meghatározó közgazdásza, Schumpeter is érdemesnek tartotta az evolúciós alaplogikákat a közgazdaságtanba átültetni. Mint ahogy arra Shionoya (2008) felhívja a figyelmet, Schumpeter a fejlődést és az evolúciót kezdetben lényegében azonosan értelmezte. Hagemann (2008) rámutat, hogy Schumpeter, korai híres múve - A gazdasági fejlődés elmélete - legkorábbi változatában még rendre az evolúció kifejezést használta a fejlődés helyett. Még a címében is. Schumpeter ugyanakkor Shionoya (2008) szerint később már felismerte, hogy bár a gazdasági evolúció folyamatában igen nagy a tudás, a tudatosság szerepe, egyáltalán nem nyilvánvaló, hogy a rövid távon sikeres innovációk - azaz variánsok - hosszabb távon is a gazdaság kedvező minőségi átalakulását, azaz fejlődését eredményezik. Nazaretyan (2003) szerint az is előfordulhat, hogy a gazdaságban az aktuális 
feltételekhez való, rövid távú hatékony alkalmazkodás felszámolja a hosszabb távú fennmaradás alapjait. Más esetekben a körülmények drasztikus megváltozása utólag teljes mértékben tévúttá teszi a korábbi legnagyobb mértékủ megfelelést, illetve alkalmazkodóképességet is. Ezt nevezzük evolúciós zsákutcának. Az evolúciós zsákutca a biológiában sem túl gyakori, a gazdasági evolúcióban pedig még ritkább. Deng (2003) szerint jelenleg is még számos fejlődési alternatíva létezik, s az érintett gazdaságok döntéshozóinak döntési időhorizontja még messze nem éri el a feltételezett végjáték kezdetét. Ezekben az esetekben tehát legfeljebb fejlődési zsákutcákról beszélhetünk. Stiglitz és Greenwald (2016) az ún. tanuló társadalomról szóló elmélete során távol tartja magát a gazdasági evolúció specifikus részterületeitől, az ezekről folytatott vitáktól, és csak a gazdasági evolúció fentebb is vázolt alaplogikájára fókuszálnak. Stiglitz és Greenwald (2016:188-190) szerint azok az országok lehetnek a jövőben sikeresek vagy relative sikeresebbek, melyek képesek a gazdasági evolúció fő problémáit enyhítve megteremteni és fenntartani a társadalom alkotó- és tanulási képességeit. Álláspontjuk szerint a gazdasági evolúció hatékonysága ellen dolgozik az:

- ha a profitot kizárólagos szelekciós kritériumként, a megfelelőség kizárólagos mércéjeként alkalmazzák;

- ha a szereplők tervezési időhorizontja rövid;

- ha a gazdasági verseny már rövid távon eldőlhet;

- ha a negatív externáliákat kibocsátók, azaz az irracionális bőség haszonélvezői tartós evolúciós előnyhöz juthatnak.

\section{A szelekciós követelmények}

Nelson és Winter (1982) álláspontja szerint a szelekciós kritériumok azok a követelmények, melyeknek való megfelelés szintje szerint határozódik meg a túlélés valószínűsége, illetve a túlélés állapoti jellemzői, azaz a túlélés kondíciói. Nelson (1995) a gazdasági evolúció vonatkozásában megkülönböztette a természeti környezet által támasztott feltételekből álló biológiai szelekciós kritériumokat az ember által létrehozott „kulturális” szelekciós kritériumoktól, s a gazdasági szelekcióban a mindenkori szelekciós kritériumokkal nagyobb mértékű összhangban álló - „fitt” - szereplő jobb eséllyel válik túlélővé az adott időszakban, méghozzá olyan kedvező állapotban, amely később több érdemi és pozitiv lehetőséget biztosít számára. A szelekcióban előnyt élvező szereplő tehát a jövőben rendre relatíve „többet megengedhet magának", mint a szelekciós kritériumokkal kevésbé összhangban állók. Ennek forrása lehet tudás, hatalom, egészség, idő, pénz vagy más erőforrás. Friedman (2007) megállapítja, hogy ha a sikeresebb túlélő ilyen többlettartalékokkal kezdi meg a következő időszakot, az relatíve nagyobb cselekvési szabadságot, kevesebb 
kiszolgáltatottságot, több befolyásolási és hatásgyakorlási lehetőséget biztosít majd részére. Nelson és Winter (1982:262-263) a szelekciós környezet négyféle elemét különböztette meg:

- az egyes tevékenységek milyen ráfordításokat követelnek meg, s milyen hozamok érhetők el általuk;

- a mód, ahogyan a fogyasztó, vagy a szabályozó preferenciái és játékszabályai hatnak az eredményességre;

- milyen összefüggés érvényesül az eredményesség, illetve a szereplő mérete, a piaci koncentráció foka között;

- milyen módon és mértékben lehetséges tanulni a sikeres innovátoroktól, milyen mértékben segítik elő, vagy nehezítik meg a másolást.

A kulturális, mesterséges szelekciós környezeten belül is megkülönböztették a piaci és a nem piaci szelekciós környezetet. Dosi és Nelson (1994) szerint egyes szereplők - például a jogalkotók - részéről kifejezetten megfigyelhető bizonyos tervszerüség, komplexitás annak érdekében, hogy a szelekció részeredményeit - jellemzően a szelekciós környezeten keresztül - befolyásolják. Ugyanakkor a közgazdasági gondolkodásban máig hatóan nagy teret nyert az a korai (1934), Schumpeter (1980) nevéhez is köthető irányzat, miszerint mindennek az értékét végső soron a fogyasztók határozzák meg. Döntésük sugárzódik vissza egészen az alapanyag-árakig, vagy fejeződik ki az értéklánc adott helyén a munkabérek nagyságában is. Sandlin és Mclaren (2010) ezzel egyetértve hangsúlyozza, hogy végső soron a fogyasztó segít folyamatosan reprodukálni a kapitalizmust. Természetesen nem mindegy, hogy a reprodukció mennyire sikeres, különösen nem hosszabb távon.

Amelyik szereplő ún. (piaci) erőfölénnyel rendelkezik, az képes közvetlen és érdemi módon már rövid távon is hatást gyakorolni a tevékenysége által érintett szereplők, így a vevők, versenytársak vagy a beszállítók szelekciós kritériumainak meghatározódására, illetve az érintettek ezen szelekciós kritériumoknak való megfelelésre (Utton 2003). Mindeközben a szóban forgó érintettek hasonló hatásgyakorlásra az erőfölénnyel rendelkezőre csak közvetett módon és hosszabb távon, ún. koevolúció révén képesek. A hatalom nem piaci kategória. A hatalom formális, illetve informális jogosultságot jelent egy alá-fölérendeltségi viszonyban arra, hogy az azzal rendelkező a kötelezett tevékenységét irányítsa vagy érdemben befolyásolja olyan célok elérése érdekében, melyek elvileg az alá-fölérendeltség által is meghatározódott csoport sajátjai (Kornai 1993). 


\section{A csoportszelekció}

Csoport alatt az egymástól nem izolált egyének olyan érdekközösségét értjük, ahol a tagok között viszonylag rendszeresen történnek együttmúködő, reciprocitást feltételező interakciók, és ahol a tagok tevékenysége érdemi befolyást gyakorol egymás célmegvalósítási eredményességére (Bergh - Gowdy 2009). A csoporttagok tehát függnek egymástól, ezáltal bizonyos mértékú együttmúködésre, alkalmazkodásra, viszonosságra vannak rászorítva, különösen amiatt, mert ez a függés nem eseti, hanem a sorozatos interakciókból adódóan tartós jellegú. Ilyen módon csoportnak tekinthető az összes szervezet, így a vállalatok is. De csoport lehet egy utca lakóközössége, egy család vagy egy baráti kör is. A csoportok között lehet átfedés is, azaz egy személy több csoportnak is lehet egyidejúleg tagja. A tagsági viszony nem feltétlenül formális csatlakozás révén történik. Hasonlóan a szerződéskötéshez, itt is nagy szerepe lehet a ráutaló magatartásnak. Azaz a más tagokkal való sorozatos interakciók realizálódása s a többi csoporttagsági feltétel teljesülése esetén már valamely csoporthoz tartozásról beszélhetünk anélkül, hogy formális csatlakozásra vagy felvételre sor került volna. Jelen tanulmányban a csoportok közül a vállalatokra fókuszálunk. A csoport fenti fogalmával összhangban Bergh és Stagl (2003) szerint a csoportszelekció során egy-egy közösség tagja elsősorban és döntően nem a többiektől elkülönülten, önállóan vesz részt a szelekcióban, hanem egy kisebb-nagyobb közösség mint szelekciós egység részeként. llyen módon nem önmagukban az egyes egyéni jellemzőknek, hanem a releváns csoportjellemzőknek kell megfelelniük a szelekciós követelményeknek. A csoport azért létezhet, mert a társakkal többé-kevésbé összehangolt tevékenységéből, hozzájuk való „közelségéből” az egyénnek valamilyen szelekciós előnye származik, származhat: növekszik a túlélési esélye, javulhatnak a túlélési kondíciói. Ugyanakkor a csoport egésze is szelekciós előnyhöz juthat a relative nagyobb és sokszínúbb populáció, illetve a szinergiák révén. A példaként közismert döntési helyzet, nevezetesen a "nagyobb torta kisebb, vagy a kisebb torta nagyobb hányada" itt is alkalmazható. A csoport hosszabb távú múködése, fennmaradása abban is kifejeződik, hogy a csoporttagok között, illetve más csoportokkal rendre interakciók újabb és újabb sorozata zajlik le, azaz, játékelméleti terminológiával élve, sokszorosan ismételt játékok valósulnak meg.

Az ismételt interakciók, „játékok" során a csoporttagok jobban megismerhetik egymást, különböző cselekvési alternativák kombinációit valósítják meg, „próbára teszik" önmaguk és mások stratégiáit. A hosszabb időszakot meg- és túlélő csoportok „veterán” tagjai között idővel nagyobb bizalom és felelősségérzet, illetve közös értékrend és rutinok alakulhatnak ki, ami jelentősen megkönnyítheti céljaik eredményes megvalósítását. Nincs minden csoport sikerre ítélve. Csoportok alkotása, a bennük való részvétel egy lehetőség a szelekciós előnyök megszerzésére. De 
mint minden lehetőség esetében, ezzel is tudni kell megfelelően élni ahhoz, hogy végül az egyén, utólag sikeresnek ítélhesse meg egy-egy időszak csoporttagságát. A gazdasági csoportszelekció során nincs kizárva az sem, hogy minden csoport abszolút mértékben erősítse túlélési jellemzőit (Polignac 1995) annak ellenére, hogy egymáshoz képest lényegi különbségek maradhatnak fenn, keletkezhetnek vagy növekedhetnek.

Mindezek mellett az is, hogy hogyan alakul a csoport, a populáció mérete, szintén a csoportszelekciós előnyszerzés egyik lényeges kritériuma (Bergh - Gowdy 2009). A csoport mérete olyannyira a siker fokmérője, hogy Avilés (2002) szerint az egyének körében általános, hogy két csoportalternatíva esetén a nagyobb méretű csoporthoz kívánnak inkább csatlakozni. Barry (1961) rámutatott, hogy a városok egy bizonyos lakosságszám alá csökkenésével az összeomlás jeleit kezdik mutatni, mivel az elvándorlás öngerjesztő folyamattá válhat. Egy bizonyos városméret elérése viszont éppen ellenkező irányú öngerjesztő folyamatot generál. Diamond (2009) számos történelmi példával bemutatta, hogy egy emberi közösség sérülékennyé válik, s a közvetlen fizikai túlélése kerül veszélybe, ha - egyéb feltételek együttes teljesülése mellett - a csoportméret a kritikus szint alá csökken, s nincs mód a tagok utánpótlására. Napjainkban a modern piacgazdaságokban egy csoport tagjainak fizikai léte nem foroghat veszélyben, ugyanakkor nagyon is valóságos maguknak a csoportoknak - vállalatoknak, szervezeteknek, népességnek, piacoknak, iparágaknak, ügyfélköröknek és egyebeknek - a hanyatlása, megszűnése. Jól tudjuk, ez a piacgazdaság múködésének elkerülhetetlen sajátossága. Mégis, ha olyan csoportról van szó, amely iránt elkötelezettek vagyunk, tenni szeretnénk a hanyatlás, megszűnés ellen. Másrészt - mint azt a következőkben látni fogjuk - egyáltalán nem mindegy, hogy egy csoport azért marad-e alul a szelekcióban, mert a fontos, lényegi szempontokat figyelembe véve a többi csoporthoz képest nem elég jó a teljesítménye, vagy azért, mert homok került a szelekció működési mechanizmusának fogaskerekei közé.

\section{Stakeholder-bázis és a potyautasok}

Az ún. stakeholder-elmélet elsősorban Edward Freeman (1984), a stratégiai menedzsment elméletének képviselője nevéhez köthető, és azt kívánja megjeleníteni, hogy nemcsak a tulajdonosok és munkavállalók közös akarata szerint épül fel egy vállalat, hanem arra lényegi hatást gyakorolhatnak más érdekeltek is. Masahiko Aoki (1984) a játékelmélet módszertani eszközrendszerét használva a vállalat mint környezetétől elkülönült rendszer belső intézményeinek kialakulásán és változásán keresztül mutatja be a vállalati létet meghatározó alapösszefüggéseket. Clarkson (1995) a stakeholder-csoporton belül megkülönbözteti az elsődleges és a másodlagos érintetteket. Az elsődleges stakeholderek közé azok tartoznak, akik támogató 
együttmúködése, azaz a vállalati döntéshozatalok során ehhez szükséges megfelelő érdekelismerés nélkül a vállalat léte, túlélése egyáltalán nem biztosítható. Ide tartoznak általában véve a dolgozók, a menedzsment, a tulajdonosok, de ezen túl akár egy múködési engedélyt kiadó hatóság is elsődleges stakeholder lehet - a szükséges ideig. A másodlagos csoport tagjai szintén fontosak, de az ő támogatásuk „csupán” a vállalat hatékonyságát növeli, a valószínú túlélés állapoti jellemzőire hat pozitivan. Mitchell et al. (1997) szerint ahhoz, hogy valaki stakeholder legyen, három feltételnek kell együttesen megfelelnie. Legyen a vállalat múködése által érintett, ez az érintettség legyen valamilyen szempontból fontos számára, és legyen valamilyen hatalma a vállalat müködésére hatást gyakorolni. Freeman és Liedtka (1997) már egyenesen stakeholder-kapitalizmusról beszél. Vagyis a kapitalista vállalati létnek, fejlődésnek a motorja a más rendszerekhez képest kiterjedtebb és erősebb stakeholder-bázis. Mivel a stakeholderek mindegyikére valamilyen hatással van az adott vállalat, szervezet, illetve tevékenység, így vagy kezdeményezőként, vagy szenvedő, illetve fogadó félként, de közvetlenül-közvetve valamennyien résztvevői a releváns interakcióknak. Ilyen módon - függetlenül attól, hogy milyen más csoportban is érdekeltek mint tagok - valamennyien egy hajóban, méghozzá csoportként eveznek a szelekció tekintetében. A pozitív módon érintetteknek ez természetesen inkább előny, a negatív módon érintetteknek pedig inkább hátrány.

A közösségek működését megterhelő, ún. potyautas probléma egyik legismertebb elemzése Hardin (1968) nevéhez köthető, s témája a közlegelők tragédiája. Ezt megelőzően Olson (1965) adta meg az általános elméleti kereteket. Eszerint egy csoport által létrehozott közös javak egy részét egy tényleges, vagy egy potenciális csoporttag magánjószágként kisajátítja úgy, hogy eközben a magánjószággá vált közös jószág létrehozásának terheiből nem, vagy aránytalanul kis mértékben veszi ki a részét. A potyautas-magatartásnak az lesz a következménye, hogy a csoport teljesítménye, hatékonysága csökken, vagy relatíve alulmúlja azt a szintet, ami a potyautasok nélkül elérhetővé vált volna. A potyautas kifejezés nem cseng olyan rosszul, mint amilyen negatív hatást gyakorolhat az adott csoportra a csoportszelekció során. Újabban a potyautas-tevékenységet a csoportot terhelő negativ externáliaként is azonosítják, függetlenül attól, hogy tényleges csoporttag, vagy csak potenciális csoporttag által kerül megvalósításra (Milgrom 1987; Laffont - Tirole 1988; Rey - Salanié 1996). A potyautas csoporttagok nem valódi, csak áltagok a csoportszelekció fogalmi keretei között. Míg korábban a potyautas-tevékenységre szinte úgy tekintettek, mint a nagyobb csoportok természetes, azaz elszenvedni kénytelen velejárójára, a későbbi megközelítések negatív externáliaként már sokkal inkább csökkenthetőnek, és csökkentendőnek is tartják azt. 


\section{A kontraszelekció és a negatív szelekció}

Lényeges tisztázni már e fejezet legelején, hogy jelen tanulmány nem kíván normatív módon közelíteni a szelekciós követelményekhez. Nem cél a szelekciós követelmények ,jóságának”, így például a fenntarthatóság szempontjából való megfelelőségének a vizsgálata. A gazdasági evolúció folyamatában a kontraszelekció és a negatív szelekció olyan jelenségek, melyek függetlenül attól létrejöhetnek, hogy a gazdasági fejlődés szempontjából ténylegesen milyen szelekciós követelmények állnak fenn. Utólag sok szelekciós követelményről bizonyosodik be, hogy kifejezetten káros hatásuk volt. Ez a próba-hiba módszerből adódó sikertelenség ugyanakkor mind a biológiai, mind a gazdasági evolúciónak nyilvánvaló sajátja.

A kontraszelekciónak már a neve is kifejezi, hogy itt olyan, nem szokványos dologról, egy „,szelekciós anomáliáról” van szó, ahol kifejezetten a szelekciós követelmények ellenében valósul meg a szelekció. Nem emberi sandaság vagy rossz szándék miatt, hanem mert bizonyos javak, helyzetek, tevékenységek tekintetében az érintett szereplők tudása nem elégséges ahhoz, hogy olyan szelekciós követelményeket állítsanak fel, melyeknek képesek is érvényt szerezni. Ennek következtében olyan gazdasági szereplők kénytelenek a csoportot - így például az iparágat, piacot, vállalatot, szervezetet - aktuálisan elhagyni, akik egyébként az általuk eloállított termékekkel, szolgáltatásaikkal, tevékenységükkel, illetve teljesítményükkel relatíve a leginkább kielégítik a releváns szelekciós követelményeket. A gazdaságilag kikényszerített távozás oka az, hogy a szelekciós követelményeknek való nagyfokú megfelelés miatt a legmagasabb minőségúnek tekintendő termékek, szolgáltatások, tevékenységek, teljesítmény, illetve az azt előállító szereplő mindezért nem kapja meg az arányosan neki „járó”, relatíve legmagasabb ellenértéket. Nem kapja, de nem is kaphatja meg, mivel az ellenértéket megállapító, biztosító másik gazdasági szereplő a hátrányára fennálló információs aszimmetria miatt nincs olyan helyzetben, hogy a szelekciós követelményeknek való megfelelés szintjét legalább közelítóleg egzakt módon meg tudja állapítani. Az ellenérték tehát csak becslésként határozódik meg, s alapja nyilvánvalóan csak egy várható minőség-érték lehet. Ilyen módon a relatíve legmagasabb minőséget nyújtani képes szereplők számára szóba jöhető ellenérték szükségképpen jelentősen alulértékeli azok erőfeszítéseit. Ez vezet ahhoz, hogy a csoportból kilépve olyan csoportot keressenek, ahol releváns erőfeszítéseiket megfelelő szinten és módon honorálják. Fontos megjegyezni, hogy az ellenérték nemcsak pénz, illetve pénzben kifejezhető érték lehet, hanem például erkölcsi elismerés is. Mivel egy-egy időt követően érzékelhetővé válik az, hogy a magasabb minőség letéteményesei távoztak, a megmaradó csoporttagok számára újabb és újabb becsült ellenértékek kerülnek megállapításra, rendre alacsonyabb szinten. Amennyiben nem történik valamilyen megoldás 
a minőség értékelésének e problematikájára, úgy Akerlof (1970) szerint a csoport idővel felmorzsolódik.

A mindennapokban olyan folyamatokat is a kontraszelektív jelzővel illetnek, melyek valójában az ezt követően tárgyalt negatív szelekció megjelenési formái. A kontraszelekció során ugyanis a szelekció által sújtott szereplő az általa előállított termékkel, szolgáltatással, tevékenységgel, leadott teljesítménnyel valamennyi aktuális szelekciós követelményt relatíve a legmagasabb szinten kielégíti, de mégsem juthat hozzá a relative arányos ellenértékhez. Ebben a rejtett információk akadályozzák meg a rendszert. Ellenben az alábbiakban tárgyalt negatív szelekció esetében az alulértékelt szereplő - miközben az összes többinek igen - egy fontos szelekciós követelménynek nem képes kellő mértékben megfelelni. Ez vezet egy hasonló megjelenési formájú jelenséghez, mint amelyet a kontraszelekció során láthattunk. Az alulértékelt szereplők problémája itt az, hogy nincsenek kellően erős alkupozícióban. Nemcsak, hogy nincsenek erőfölényben vagy hatalmi pozícióban az ellenérték megállapítójával szemben, de kifejezetten gyenge az érdekérvényesítő képességük. Ez a szelekciós követelmény ugyan nem közvetlenül a szereplő által előállított termékekhez, szolgáltatásokhoz, tevékenységhez vagy létrehozott teljesítményhez közvetlenül kapcsolódó szelekciós követelmény, de mégiscsak az.

Tirole (2016) megállapítja, hogy összességében a szelekció lehet negatív vagy pozitív. A kettő közötti különbségtétel megfelelő objektivitás biztosítása mellett ténylegesen is lehetséges. A pozitív szelekció révén az érintett közösség fejlődhet. Tirole szerint például ilyen, amikor a piac bővül, ami ugyanakkor olyan jellemzőkben is megnyilvánul, mint a meghatározó tényezők minőségének javulása, aminek révén a releváns aktivitások hatékonyabbá válhatnak. Egy piac esetében ez alacsonyabb árszintet jelent változatlan termékre vetítve, miközben a termelői oldal is hosszú távon képes megőrizni profitabilitását. A negatív szelekció azonban a hatékonyságot valamilyen módon aláássa, rombolja, amelynek előbb-utóbb kedvezőtlen következményei lesznek a közösség számára. A kontraszelekció és a negatív szelekció összehasonlítását az 1. táblázatban foglaltam össze. 


\section{1. táblázat}

A kontraszelekció és a negatív szelekció összehasonlítása

\begin{tabular}{|c|c|c|}
\hline Szempont & Kontraszelekció & Negatív szelekció \\
\hline $\begin{array}{l}\text { Kik kerülnek szelekciós } \\
\text { hátrányba }\end{array}$ & $\begin{array}{l}\text { Az általuk előállított jószággal } \\
\text { vagy tevékenységükkel, } \\
\text { teljesítményükkel az összes } \\
\text { szelekciós kritériumnak leginkább } \\
\text { megfelelők }\end{array}$ & $\begin{array}{l}\text { Az általuk előállított jószággal } \\
\text { vagy tevékenységükkel, } \\
\text { teljesítményükkel az összes - } \\
\text { kivéve } 1 \text { db - szelekciós } \\
\text { kritériumnak leginkább } \\
\text { megfelelők }\end{array}$ \\
\hline $\begin{array}{l}\text { Milyen kört érint közvetlenül } \\
\text { hátrányosan a szelekció }\end{array}$ & Külső és belső stakeholder & Külső és belső stakeholder \\
\hline Hátrányba kerülők hiányosságai & $\begin{array}{l}\text { Nem tudja kifelé jelezni a magas } \\
\text { minőségét }\end{array}$ & $\begin{array}{l}\text { Nincs alkuereje, alárendelt } \\
\text { pozícióban van }\end{array}$ \\
\hline Hátrányt okozók jóhiszemúsége & Jóhiszeműek & $\begin{array}{l}\text { Jogaikkal - erőfölényükkel, } \\
\text { hatalmukkal - visszaélnek }\end{array}$ \\
\hline $\begin{array}{l}\text { Hátrányt okozók célja } \\
\text { a szelekciós hátrány okozásával }\end{array}$ & Nem célzatos a hátrány okozása & $\begin{array}{l}\text { Magánérdek a belső } \\
\text { stakeholderek ellen, rövid távú } \\
\text { csoportérdek a külső } \\
\text { stakeholderek ellen }\end{array}$ \\
\hline Hatás a csoportlétszámra & Folyamatos tagvesztés & $\begin{array}{l}\text { Kezdetben egy ideig nem, később } \\
\text { folyamatos tagvesztés }\end{array}$ \\
\hline Folyamat végkimenete & Csoport megszűnése & Csoport megszűnése \\
\hline $\begin{array}{l}\text { Felszámolási, visszaszorítási } \\
\text { lehetősége }\end{array}$ & $\begin{array}{l}\text { Információs aszimmetria } \\
\text { megfelelő szint alá csökkentése }\end{array}$ & $\begin{array}{l}\text { Visszaélés szankcionálása } \\
\text { releváns szelekciós } \\
\text { kritériumokkal, és/vagy } \\
\text { a visszaélők elkötelezettségének } \\
\text { megteremtése által }\end{array}$ \\
\hline A jelenség megjelenési formái & $\begin{array}{l}\text { Minőségtől független egyenlő } \\
\text { elbánás rejtett információ mellett }\end{array}$ & $\begin{array}{l}\text { 1) Minőségtől független egyenlő } \\
\text { elbánás rejtett információk } \\
\text { nélkül; } \\
\text { 2) Eseti és kollektív puha } \\
\text { költségvetési korlát; } \\
\text { 3) Monopólium eröfölénnyel való } \\
\text { visszaélése; } \\
\text { 4) Korrupciós rejtett tevékenység; } \\
\text { 5) Status quo megőrzése vagy } \\
\text { megváltoztatása a magasabb } \\
\text { minőség visszaszorítása } \\
\text { mellett. }\end{array}$ \\
\hline
\end{tabular}

\section{A kontraszelekció és a negatív szelekció alaptípusai a mindennapokban}

Mint azt az előzőekben láthattuk, a látszólag kontraszelektív folyamatok többsége mögött valójában negatív szelekció áll, nem pedig valódi kontraszelekció. Mint azt az összefoglaló fejezetben látni fogjuk, az erőfölény, vagy a hatalom önmagában szintén nem káros a szelekció szempontjából, hiszen azt sokféle módon lehet felhasználni. A negatív szelekció problémája lényegében akkor keletkezik, amikor az 
erőfölénnyel, a hatalommal célzatosan azokkal szemben történik a visszaélés, akik egyébként - az érdekérvényesítés kivételével - valamennyi szelekciós követelményt a legmagasabb szinten kielégítik. Az alábbiakban röviden megismerkedhetünk ",a” kontraszelekcióval, illetve a negatív szelekció azon típusaival, melyek jelentősek a gazdasági szelekció vonatkozásában.

\subsection{Minőségtől független, egyenlő elbánás rejtett információ mellett}

George Akerlof híres tanulmányában (1970) bemutatja, hogy egy piacon a keresleti és kínálati oldal között fennálló információs aszimmetria miként eredményezhet kontraszelekciót (adverse selection), ami végső során a piac összeomlásával is végződhet. A folyamat a nagyfokú és növekvő bizonytalanság miatt erősödhet így fel, miután a piacon nem múködnek - egyértelmú szelekciós kritériumként - olyan intézmények, melyek e bizonytalanságot minimalizálhatnák. Akerlof modelljében a vevők nem képesek megítélni a termék valós minőségét, ezért kényszerülnek arra, hogy azt szisztematikusan és fokozódó mértékben alulárazzák. Mindez a valójában magasabb minőségű termékkel jelentkező - ebből a szempontból magasabb minőségű - eladókat ugyancsak fokozódó mértékben tartja távol a piactól. A - jobb hiján - átlagminőségűnek feltétezett átlagjószág legfeljebb átlagárat kaphat, ami a magas minőséget szállító eladónak hátrányos, míg az alacsonyabbnak előnyös helyzetet teremt. ${ }^{2}$ Ebben az esetben tehát a vevők a rejtett információk miatt nem képesek megítélni a termékminőséget, s valamilyen megoldás intézményesülése hiányában ez a piac leépülését eredményezi. A kontraszelekció ebben az esetben a vevő oldali szereplők tudáshiányának következménye, méghozzá nem szándékolt módon. A vevők kifejezetten szeretnék felismerni a magasabb minőséget, áldoznának is rá ezzel arányosan többet, de erre képtelenek. ${ }^{3}$

Arrow (1979) még az árak bizonytalanságánál is jelentősebbnek ítélte a megvásárolandó áru minőségének bizonytalanságát. Az ár és a nem ár jellegü - például minőségre vonatkozó - jelzések egyformán szerepet játszanak a gazdasági szereplők döntései során. Ha egy biztosítótársaság nem képes a lehetséges ügyfelek rossz minőségú hányadának kiszűrésére, teret nyerhet a kontraszelekció jelensége, s egyre inkább a legmagasabb kártérítésre igényt tartható ügyfelek kötnek majd biztosítást a rossz portfólió miatti magasabb áron. Ahogy romlik az ügyfélportfólió s emelkednek a biztosítási díjak, úgy maradnak egyre inkább távol a biztosítási piactól a jó minőségű ügyfelek. A társaságnak tehát erőfeszítéseket kell tennie annak érdekében, hogy a jó és a rossz minőségú ügyfeleket megkülönböztetve egymástól - screening, szürőelmélet (Spence 1973; Stiglitz 1975) -, mindenkinek arányos biztosítási díjat tudjon ajánlani. A nem ár jellegú jelzések, információk felkutatására, kikényszerítésére fordított kiadás megtérülhet ezáltal. Mint ahogy azonban arra

\footnotetext{
${ }^{2}$ Major (2014) kormány és a gazdasági szereplők viszonyrendszerével, kétoldalú aszimmetrikus információs helyzetével kapcsolatos kutatása ezzel összecsengő megállapításokhoz vezetett.

${ }^{3}$ Vincze $(1991 a, 1991 b)$ nagy alapossággal elemezte a kontraszelekció kialakulásának ezt a modelljét.
} 
Bester (1985) is rámutat, lényeges a szürés szigorúságának finomhangolása. Túl nagy szigor - a minőségi ügyfelek egy részének elvesztésével - ugyanúgy hanyatlásba taszíthatja a piacot, mint a kontraszelekciós folyamatok térnyerése. A túl laza szigor túlzott kockázatoknak teszi ki a vállalat müködését. A jó minőségü ügyfeleknek is érdekük arra vonatkozóan hiteles jelzést kibocsátaniuk - signaling, jelzéselmélet (Spence 1973) - hogy ők jó minőségű ügyfélnek számíthatnak. Rothschild és Stiglitz (1976) a biztosítási piac múködését szimuláló, nagy hatású modelljében bemutatja egyrészt, hogy a magasabb minőségú ügyfelek a biztosítóval való kockázatmegosztás - önrész - magasabb fokával jelzik, fejezik ki alacsonyabb kockázati jellemzőiket. Természetesen a szűrés ismétlődő alkalmazása a piac egyik oldalán a másik oldali szereplőket arra ösztönözheti, bizonyos piacokon kényszerítheti, hogy a szürés feltételrendszerének eleget tevő jelzéseket tudják magukról kibocsátani (Riley 1989).

\subsection{Minőségtől független, egyenlő elbánás rejtett információk nélkül}

A negatív szelekció típusai közül elsőként tekintsük át azt, amikor a szereplő az input oldalon nem tesz különbséget az eltérő minőség között, akár a beszállítók, akár az alkalmazottak tekintetében. Ebben az esetben a szereplő megfelelő információkkal rendelkezik az inputok viszonylatában, fontos is számára az inputok tekintetében az, hogy minél magasabb minőséghez jusson. Azonban erőfölényével visszaélve megkísérli, hogy a magasabb minőséghez olyan áron jusson hozzá, mint amely az alacsonyabb minőség esetében szokásos. Vagyis az inputok árazása nem minőségfüggő. Nyilvánvaló, hogy a piac alaplogikája szerint a szereplő ebben az esetben csak akkor juthatna hozzá a magasabb minőségű inputokhoz, ha azok előállítása az ott érintett szereplők kisebb ráfordításával járna. Az esetek jelentős részében azonban ez nincs így. Mi biztosíthatja mégis azt, hogy a szereplő a számára előnyösebb, magasabb minőségú inputokhoz is tartósan olyan, alacsonyabb áron juthasson hozzá, amely csak az alacsonyabb minőség mellett biztosít kellő jövedelmet az input oldali érintettek részére? Kegan és Lahey (2017) szerint a gazdasági szereplők jelentős részében komoly ellenállás tapasztalható bármilyen változással szemben. Esetünkben a változás a magas minőséget előállító inputoldali érintett számára azt jelentené, hogy számára kisebb ráfordítást igénylő, alacsonyabb minőségű input előállítására kellene berendezkednie. Ez eleve csak a beszállítók esetében lehetséges, hiszen egy alkalmazott már nem teheti semmissé a végzettségét, tapasztalatait vagy egyéb megszerzett képességét, kompetenciáit. Számára, amennyiben nem tud megfelelő alkupozícióba kerülni, nem marad más, mint elfogadni a hatalommal a hátrányára történő visszaélést, vagy más, perspektivikusabb csoporthoz csatlakozni. Ezt a csapdahelyzetet széleskörüen elemzi Hirschman (1995) Kivonulás, tiltakozás, hüség címü munkájában.

A beszállítók esetében viszont a „minőségrontó”, termelési eljárásokat ki is kell dolgozni, meg kell tanulni, ez is erőfeszítést igényel. A tehetetlenség a korábbi esetünkben magasabb minőségi - szinten rögzítheti a termelést (Schumpeter 1980). 
A technológiaváltás kapcsán fellépő, a változtatástól való tartózkodás időtartamában megmutatkozó termelői tehetetlenség mértékét jelentősen befolyásolja a szereplő mérete, tudása s jövedelme (Dong - Saha 1998), másrészt a termelő stratégiát alkotó tulajdonosai, vezetői vagy a dolgozók kulturális beágyazottsága, normarendszere nem teszi lehetővé a minőség szándékos csökkentését még akkor sem, ha az növelné a szereplő nyereségességét, túlélési esélyeit (Solow 1979). Amennyiben a magas minőségű, „lehető legjobb” jószág előállítása mélyen beágyazott normákon, szokásokon, esetleg valláson alapul, úgy ezek akár évtizedekig, generációkon át is képesek tartani magukat (Williamson 2000), még akkor is, ha a minőséggel nem arányos az ellenérték. A magasabb minőségre való törekvés intézményének beágyazottsága nélkül is gyakran előfordul, hogy az elkötelezettség személyes vagy csoportszintű. A relatíve magasabb minőség eltűnését e szereplők krízisként élik meg, s e krízist egyrészt a magasabb minőség intézményesítésével, másrészt az azzal arányos piaci ár elfogadásával, elfogadtatásával kívánnák megszüntetni, amennyiben ehhez megfelelő alkupozícióval, érdekérvényesítő képességgel rendelkeznének (Sylvander et al. 2006:63).

A második altípus a kollektív jutalom és büntetés esete. Mindkét fogalom kétkomponensü. Ahogyan Avnar Greif (2006) rámutatott, a kollektív büntetés esetén egy közösség valamennyi tagja részt vesz a szabályokat megsértve tevékenykedő szereplő büntetésében, függetlenül attól, hogy a közösség mely tagját érte közvetlenül sérelem. A közösség azon tagja, aki nem vesz részt a vétkes megbüntetésében, maga is büntetésben fog részesülni. Ugyanakkor - még akkor is, ha magányos bünelkövetőről van is szó - nemcsak egy személy fog bűnhődni, hanem az őt magába foglaló csoport is. A középkori „maghribi kereskedő"k” esetében ez azt jelentette, hogy a kereskedői közösség azon tagja, aki súlyosan szabályt sértve járt el, többé nem kereskedhetett mással, egyfajta sajátos bojkott alá került. Ez könnyen kiterjedhetett szúkebb csoportja több tagjára vagy egészére is, függetlenül attól, hogy a többi érintett csoporttag nyilvánvalóan nem követett el búnt. A kollektív büntetés tehát a szűkebb csoport iránti erősebb elkötelezettséget is a nagyobb csoport javára kívánta fordítani. Ennek a büntetésnek nagyon erős a megfélemlítő ereje. Hasonló az alaplogikája az ókori római tizedelésnek is. A kollektív jutalomnak is hasonló az alaplogikája. Tehát nem arról van szó, hogy - elvileg - ne lehetne egyértelműen azonosítani a közösség jutalomra érdemes tagjait, vagy ne lehetne közöttük differenciálni, hanem inkább arról, hogy a csoport egészének jutalmazása erősebb hajtóerőt biztosít a tagok együttmúködésének fokozására. Narloch et al. (2012) szerint a kollektív jutalmazás rendszere akkor múködőképes, ha a csoport tagjai megfelelően homogének mind egyéni jellemzők, mind az érdekek tekintetében. A rendszer feltételezi a megfelelő csoportkohéziót, illetve a csoporton belüli együttmúködést is. Ahol azonban mindezek hiányoznak, ott a csoportmunkához relatíve nagyobb mértékben, nagyobb ráfordításokkal, jelentősebb áldozatokkal hozzájáruló csoporttagok könnyebben felélhetik tartalékaikat, miközben a kollektív jutalom rájuk 
eső része nem kompenzálja őket mindezért (Willer 2009). Nem összetartó, nem kellően homogén közösségben a kollektív büntetés hasonlóan nagy hátrányt jelent azoknak, akik egyébként relatíve a legmagasabb szinten teljesítették a szelekciós követelményeket, de többlet-erőfeszítéseik megtérülésére nincs mód, és azonos hátrányt kell elszenvedniük, mint a többieknek. Elsőként ezeknek a szereplőknek lehetetlenül el a múködése, tevékenysége (Heckathorn 1993). Kiemelendő, hogy az is kollektív büntetésként értelmezendő, ha ténylegesen nincs formális kollektív büntetés, de jutalom sem. Ahol tehát egy közösség már eleve nem kellően homogén, összetartó és együttmúködő, s bár nincsenek kollektív büntetések, de differenciált jutalmazási rendszer sincs, ott bizonyosan szembesülniük kell a negatív szelekció következményeivel.

\subsection{Eseti és kollektív, puha költségvetési korlát}

Kornai János (1997) a puha költségvetés korlát elemzésekor rámutat arra, hogy kemény költségvetési korlát esetén létkérdése a szereplőnek, hogy jövedelmükből megfelelő hatékonyságot elérve fedezni tudják kiadásaikat. Puha költségvetési korlát mellett azonban a szereplő számára a költségvetés korlát már nem képezhet szűk keresztmetszetet. Akinek e szelekciós követelmény áldozatává kellene válnia, azok is tovább múködhetnek, hiszen tényleges vagy - a hatékonyabbakhoz képest - relatív veszteségeik idővel fedezésre kerülnek. Amennyiben az állam a megmentő, úgy közvetlenül, vagy közvetve, a sikeres szereplők nyereségét elvéve teremti elő a forrásokat e veszteségfedezéshez, jövedelempótláshoz. Amennyiben a vállalat jövedelmezősége nem befolyásolja jelentős módon a vezetők javadalmazását, akkor nincs meg a kellő ösztönző erő ahhoz, hogy a vezetés lényegi erőfeszítéseket tegyen a költségek csökkentésére, a nyereségesség növelésére (Kornai et al. 2004). Ugyanez a helyzet a beosztottak vonatkozásában is: a sikeres újításnak nincs, vagy jelentéktelen a jutalmazása a központ részéről még vezető szinten is, ami alig érinti a feladatot ténylegesen elvégzőket (Kornai 2010). A puha költségvetési korlát jelenléte egy csoportban még nem feltétlenül jár együtt a negatív szelekcióval. Kornai (2008) bemutatja, hogy a hazai kórházak esetében évi gyakorisággal rendszeressé váló állami adósságkonszolidáció, „kimentés” azt eredményezi, hogy a kórházak egyöntetűen alkalmazkodnak ehhez a gazdálkodási környezeti jellemzőhöz. Azok is, amelyek a többi szelekciós követelménnyel relatíve nagyobb összhangban vannak - élen járnak a gyógyításban, megelőzésben, illetve általában a gazdálkodás terén - és azok is, amelyek nem. Ilyen módon a magasabb minőséget képviselő kórházak csak azért, mert nagyobb összhangot mutatnak a szelekciós követelményekkel, még nem kerülnek szükségképpen hátrányba, azaz jelenleg a hazai kórházak között nincs negatív szelekció. Nyilvánvalóan nagy hatékonysági rések mellett gazdálkodnak és múködnek több szempont szerint is, de szelekciós hátrányt nem kell a magasabb minőséget képviselő kórházaknak elszenvedniük. Ugyanakkor igaz, hogy annak, hogy a kórházak minden év végén állami mentőövre szorulnak, meghatározó oka az állam általi év közbeni, költséghatékonyságra ösztönözni kívánó alulfinanszírozás. Más 
a helyzet az önkormányzatok 2011 és 2014 között megvalósult adósságkonszolidációjával. A kórházakhoz hasonlóan Lentner (2014) itt sem tapasztalt negatív szelekciót, de ennek pusztán az az oka, hogy elemzésébe érdemben nem vonta be azokat az önkormányzatokat, amelyek nem halmoztak fel korábban adósságállományt, s ennek ellenére is jelentős fejlődésre voltak képesek. Egy eseti, alkalomszerű, továbbá puha költségvetési korlát túl ritkán nyilvánul meg ahhoz, hogy a kimentettek szelekciós követelményként értékelve azt, alkalmazkodjanak a létéhez. Ennek ellenére ez a jelenség is egyértelműen befolyásolja az önkormányzatok közötti szelekciót (Vigneault 2005), és ez nem is csak Magyarországra igaz. A kiegyensúlyozottan gazdálkodó önkormányzatokat az eseti, ugyanakkor általános, mindenkire kiterjedő adóskonszolidáció - puha költségvetési korlát - hátrányos helyzetbe hozza az általánosan önhibájukból eladósodottakhoz képest. Kiegyensúlyozott gazdálkodásukkal ugyanis éppen annyi „kárt” okoztak a saját önkormányzatuknak, mint amennyi adósság felvételére, majd állami konszolidálására lehetőségük nyílt volna. Ugyan hazánkban a központi kormányzat, érzékelve ezt az ellentmondásos helyzetet, kompenzálni kívánta a kiegyensúlyozottan gazdálkodó önkormányzatokat, de a kompenzáció mértéke inkább jelképes volt. Hajdúszoboszló esetében nem érte el a 10 százalékot, ráadásul mindehhez pályázni kellett. Az elnyert támogatást ugyanakkor csak olyan adott célokra lehetett fordítani, melyek a jól múködő önkormányzatok esetében már korábban lényegében megvalósultak. ${ }^{4}$ Ezzel a kisváros mintegy 3 milliárd $\mathrm{Ft}$ hátrányba került azokhoz a városokhoz képest, amelyek a hasonló turisztikai fejlesztéseiket hitelből finanszírozták.

\subsection{Rejtett korrupciós tevékenység}

A megbízó-ügynök elmélet szerint az ügynökök alapvetően a saját érdekeiket követik, amelyek konfliktusba kerülhetnek a megbízó érdekeivel. Az ügynökök döntési jellemzőinek tekintetében információs aszimmetria áll fenn az ügynökök javára, s részben ennek is a következménye, hogy az ügynökök kockázatvállalóbbak, mint a megbízók (Eisenhardt 1989). Ahhoz, hogy korrupcióról beszélhessünk, Graaf és Huberts (2008) mindezen feltételekhez még hozzásorolja azt is, hogy az ügynök a tevékenységére vonatkozó szabályokat megszegve, a saját magánérdekeit azon csoport érdekeinek a rovására érvényesítse, ahol tagként kötelezettsége, felelőssége áll fenn. A hatalmat, amivel ebben az esetben egyes csoporttagok visszaélnek, a javukra fennálló információs aszimmetria biztosítja, és meghatározott mértékủ döntési, cselekvési autonómiájuk révén teremtődik. Az Amerikai Egyesült Államokban tipikusan főként a magáncégek menedzsmentjének az ilyen visszaélésszerű gyakorlatát sorolják a korrupcióhoz (Heidenheimer - Johnston 2011:28-29), hiszen nem feltétlenül kell ahhoz állami tulajdon vagy közhivatal, hogy egy közösség érdekei illegálisan feláldozásra kerüljenek a magánérdekek érvényesítése okán. Az állami

\footnotetext{
${ }^{4}$ Magyarország 2015. évi központi költségvetéséről szóló 2014. évi C. törvény 3. melléklet II. 10. pontja szerinti, az adósságkonszolidációban nem részesült települési önkormányzatok fejlesztéseinek támogatása.
} 
szférához kapcsolódó korrupció hasonlóan fogható fel a megbízó-ügynök elmélet keretében, azzal a különbséggel, hogy a hivatalokat ellenőrző politikusok maguk is a választópolgárok ügynökei. Tehát ebben az esetben az ügynökök ügynökeiről van szó. Mint ahogyan Guriev (2004) is bemutatja, a korrupció azzal, hogy a hivatalnokok vagy a menedzserek részt követelnek maguknak a projektek kivitelezési költségeiből vagy bevételeiből, a legmagasabb minőséget irtja folyamatosan, szisztematikusan. Ugyanis a győztesek tipikusan nem a legjobbak lesznek, hiszen nekik nem lenne szükségük korrupcióra ahhoz, hogy nyerjenek. A gyengébb, „kvázi”-minőség több szabad, lefölözendő forrást biztosít a korrupció résztvevői számára. De még ha esetenként a legmagasabb minőség is kerülne kiválasztásra, akkor is gyengülne a gazdasági ösztönzés a további minőségfejlesztésre. Tehát mindenképpen fokozatosan eltűnik a minőségi jószág a piacról, egyre gyengébb minőség egyre nagyobb károkat okozhat a közösségnek. Eltorzul a verseny, jóléti veszteségeket szenved közvetve az egész társadalom (Hámori 2002). Egyes szakértők - mások mellett Huntington (1968); Leff (1964) - szerint a korrupció nem általánosan és egyértelműen káros a gazdaság fejlődésének vonatkozásában. Álláspontjuk szerint számos korrupció megnöveli a hatékonyságot, növeli a múködőképességet, az új szabályok intézményesülésének egy korai fázisaként kenőolajat jelent a gazdasági gépezet számára. Mások - többek között (Méon - Sekkat 2005) - nem osztják ezt az álláspontot. Véleményük szerint a magánérdeknek a csoportérdek rovására történő érvényesülése relative akkor is hátrányt jelent az érintett csoport számára a szelekció során, ha egyébként azok a szabályok, melyek megsértésre kerülnek, a csoport fejlődését nem segítik elő kellóképpen. Csak az az illegális tevékenység lehet ténylegesen „kenőolaj” a gépezetnek - miközben nem korrupciót, hanem más bűncselekményt valósít meg -, mely közvetlenül a csoport vélt érdekeit helyezi előtérbe. Való igaz, mindezt valószínúleg más gazdasági szereplők rovására teszi, miközben a személyes magánérdekek közvetve nyerhetnek kielégítést. Bardhan (1997) rámutatott arra, hogy az a tény, hogy a kelet-európai országok a rendszerváltást követően növekvő korrupció mellett gazdasági növekedést is képesek voltak felmutatni, nem jelenti azt, hogy a korrupció ne vetette volna vissza ezeknek az országoknak a növekedését, illetve fejlődését. Azt már soha nem tudjuk meg, hogy mennyi lett volna lényegesen kisebb korrupció mellett ezeknek az országoknak a növekedési üteme. Az azonban bizonyos, hogy a korrupció által szükségképpen visszaszorultak, hátrányba kerültek olyan gazdasági szereplők, amelyek csak egyetlen szelekciós követelményt nem voltak képesek magas szinten kielégíteni, nevezetesen nem volt meg a kellő alkupozíciójuk, hiányzott a megfelelő érdekérvényesítési képességük. A negatív szelekció tehát azokat a szereplőket hozta, hozhatta helyzetbe a korrupció által, amelyeknek kiváló volt az alkupozíciójuk, érdekérvényesítő képességük, igaz, más szelekciós követelményeknek kevéssé voltak képesek megfelelni. Ezzel összhangban Mo (2001) számított becslései szerint 1 százalékos növekedés a korrupció szintjében 0,72 százalékkal csökkenti a gazdasági növekedést, illetve másképp kifejezve, a korrupciós index egy egységnyi növekedése 0,545 százalékponttal csökkenti a gazdasági növekedést. 


\subsection{Monopólium diszkriminatív fellépése a legjobb ügyfelek kárára}

Lambsdorff (2002) szerint a monopóliumok lényegében - döntő többségükben - az államnak a gazdaságba való beavatkozása révén jönnek létre. Általuk vagy maga az állam kíván járadékokra szert tenni, vagy más gazdasági szereplő részére kívánja azokat biztosítani. A járadékvadászat és a korrupció között nyilvánvaló az összefüggés Lambsdorff szerint. De járadékra nem csak illegálisan, nem csak korrupció révén lehet szert tenni. A monopólium legálisan is képes járadékokat biztosítani tulajdonosai részére (Hillman - Katz 1984). A monopóliumok jellemzően kétségtelenül erőfölénynyel rendelkeznek, ez azonban nemcsak a piaci részesedésükből, hanem a keresleti jellemzőkből - például annak eltérő rugalmasságából - is adódik (Pindyck 1985). A közgazdaságtan érdeklődése régóta kiterjed a monopóliumokra. A mikroökonómiai tankönyvek kihagyhatatlan részét képezi a monopólium által okozott társadalmi holtteher-veszteség, illetve alkalmazott árdiszkrimináció tárgyalása. Mindezek után szükségszerúnek tűnt, hogy a monopóliumokat a piaci kudarcok egyik alaptípusának tekintsék (Stiglitz 1986). Ugyanakkor Vickers (2005) hangsúlyozza, hogy nem a relatíve magasabb árakban nyilvánulhat meg a monopólium erőfölénnyel való visszaélése, hanem abban, hogy milyen eszközökkel próbálja a monopolhatalmát megőrizni. Az erőfölény-megőrzés olyan területei, mint a verseny korlátozása vagy a tisztességtelen verseny, lehetséges, hogy méltánytalan, unfair versenyhez vezetnek, esetleg annak a teljes hiányához, s közvetve talán a fejlődést sem szolgálják. A tényleges és lehetséges versenytársakkal való bánásmód milyensége azonban nem eredményezhet negatív szelekciót. Ahogyan Baumol (1982) rámutat, a legnagyobb erőfölénnyel rendelkező, azzal a leginkább vissza is élő monopólium is csak akkor válik támadhatatlanná, ha a jelenben s várhatóan a tervezhető jövőben is a lehető legjobb ajánlattal tud vevői elé állni mind az ár, mind a minőség tekintetében. Amennyiben ez nem így van, úgy a potenciális belépők akkor is valós fenyegetést jelentenek a számára, ha nagyon komoly belépési korlátok állnak fenn. Egy monopólium tehát csak úgy tudja fenntartani monopolhatalmát, ha ő az, aki a fennálló szelekciós követelményeknek - legyenek azok bármilyen méltánytalanok is - a leginkább megfelel. Ameddig folyamatosan csak olyan kihívók, olyan tényleges vagy potenciális versenytársak maradnak vele szemben alul, akik ezeknek a szelekciós követelményeknek kevésbé felelnek meg, addig a szelekció pozitív (Schumpeter 1942). Monopólium tehát a versenytársai vonatkozásában nem okozhat negativ szelekciót. Más a helyzet azonban a beszállítói, dolgozói vagy a vevői tekintetében.

A korábbi fejezetpontokban már tárgyalásra került az input oldal - monopólium fennállásától független - negatív szelekciója, kerüljön sor most a vevői oldalra. Mussa és Rosen (1978) bemutatta, hogy a monopólium által az egyes vevői szegmentumok tekintetében alkalmazott árdiszkrimináció és minőségpolitika többféle kombinációt létrehozva sajátos eseteket eredményez. Amikor ugyanis az árdiszkrimináció egységes színvonalon nyújtott minőséggel párosul, túlságosan nagy eltérés alakulhat ki az egyes szegmentumok számára értékesített jószág ár-érték arányaiban. 
A legalacsonyabb áron hozzáférést kapó vevők a pénzükért relatíve magas minőséget, míg a legmagasabb árat fizetők relatíve alacsony minőséget kapnak ellenérték gyanánt. Utóbbiaknak tehát nem az ár a túl magas, hanem a monopólium által minőség formájában megtestesülő ellenérték. Amennyiben a legmagasabb árat fizető vevői szegmentum a monopólium által támasztott szelekciós követelményekkel a leginkább összhangban álló vevőkből tevődik össze, úgy ebben az esetben a monopólium folyamatosan a legjobb vevőit veszítheti el. Amikor a monopólium a leginkább fizetőképes vevői köre tekintetében él vissza erőfölényével, akkor jelentős mértékben fennáll a negatív szelekció kialakulásának lehetősége. Az árak jogszabályi maximálása, illetve a minőségi standardok emelése révén lehet csak megállítani a negatív szelekciót (Besanko et al. 1987). Forgács (2013) szerint a hazai egészségbiztosítás járulékbevételei a lakosság harmadától származnak, miközben lényegében a teljes lakosság jogosult az egészségügyi szolgáltatásokra. Rámutatott, hogy „az esetenként igen magas járulékot fizetők számára nehezen elviselhető, hogy ugyanolyan ellátást kapnak, mint a járulékot sohasem fizető polgártársaik. Ezt az anomáliát a német társadalombiztosítási rendszer úgy kompenzálja, hogy a felsö jövedelemi decilisbe tartozók nem is vehetik igénybe a szolidaritás alapú biztosítást" (Forgács 2013:8). A legtöbb járulékot fizetők vannak ráadásul átlagosan a legjobb egészségügyi állapotban is, tehát számukra ritkán, de akkor magas minőségben kellene ellenszolgáltatást biztosítani. Az őáltaluk biztosított forrásokról viszont a hazai egészségügy nem kíván lemondani, hiszen akkor az általános minőségi minimumokat sem lenne lehetséges tovább fenntartani. Mindez azonban folyamatos negatív szelekciót eredményez még abban az esetben is, ha formálisan továbbra is fizetik a legjobb ügyfelek a járulékot. Ügyfélként ugyanis ezeket az embereket folyamatosan elveszti az egészségügy, privát egészségügyi szolgáltatásokat vesznek igénybe, nemegyszer már külföldön. Így általuk hálapénz formájában alig áramolhat már pótlólagos jövedelem az egészségügy alkalmazottjaihoz.

\subsection{Magasabb minőség visszaszorítása a status quo fenntartásáért vagy megváltoztatásáért}

A szereplők - akár szervezetekről, akár egyénekről van szó - közötti status quo minden érintett számára meghatározó, hiszen ez jelöli ki a tevékenységi, a felelősségi, a hatalmi, illetve a döntéshozatali autonómia határait. A status quo megváltoztatása - még akkor is, ha az adott szereplő számára célmegvalósítása szempontjából kedvezőbb lehet - mindig bizonytalansággal terhes. A fennálló status quo vonatkozásában a múltbéli tapasztalatok, tanulás folytán van a szereplőnek bizonyos, több-kevesebb tudása, ehhez képest a jövőbeni status quo megítélése tekintetében ennél jelentősebb mértékben kevesebb tudás állhat rendelkezésére. Az új status quo eléréséig számos tranzakciós és egyéb költség is felmerül, ezek mértékét nem könnyű prognosztizálni, de a pótlólagos hozamokét sem. A költség-haszon elemzés mellett számolni kell a kockázatok növekedésével is, hiszen hiányosak a meglévő rutinok és képességek az eltérő jövő szempontjából, vagy legalábbis még nem estek 
át a túzkeresztségen. Ajzen (1991) a tervezett magatartás modelljében három tényező együttes hatásaként látatja a szereplői viselkedést: a szereplő tervezett magatartására, tevékenységére vonatkozó normák, a saját releváns attitúdjei, illetve a majdani tevékenység kontroll alatt tartására vonatkozó észlelései. $E$ hármasból alakulhat ki az ösztönzés olyan kritikus mértéke, amely már elégséges ahhoz, hogy a tervezett tevékenység megkezdődjön. Ugyanakkor a kontroll alatt tartás mértékét a tevékenység elkezdésével továbbra is kitüntetett figyelemmel kezelik a szereplők, mivel a legnagyobb veszélyt az ellenőrzés elvesztése jelentheti számukra. Minél több a szereplő releváns múltbeli tapasztalata, hasonló rutinja, annál valószínúbb, hogy ellenőrzése alatt tudja tartani a tervezett tevékenységet. Samuelson és Zeckhauser (1988) valamennyi piacon alkalmazható elméletükben rámutatnak arra, hogy amenynyiben egy döntési szituációban a közösségi, szervezeti normák, illetve a regulátor szabályai által megengedett a jelenlegi status quo mint alternatíva választása - azaz fenntartása -, akkor legnagyobb valószínűség szerint az kerül választásra. Amenynyiben nem megengedett, akkor pedig a jelenlegi status quo jelentette állapotokhoz a legközelebbi állapotokat eredményező alternatíva. Természetesen a mérték változhat, méghozzá egyrészt a bizonytalanság és kockázat racionális szereplőként való figyelembevétele, másrészt a kognitív eredetű hibás észlelések - információk dekódolása - miatt, harmadrészt a pszichológiai elkötelezettség eltérései okán. Mokyr (2004) szerint a technológiai haladást és a fejlődés egyéb formáit az aktuális status quo fenntartásában érdekelt személyek, csoportok hagyományosan igyekeznek blokkolni. Teszik ezt annak ellenére, hogy egyértelmúen tudatában lehetnek annak, hogy azok a termékek, szolgáltatások, eljárások, technikák, illetve általuk közvetve azok elóállítói a fennálló szelekciós követelményeknek inkább megfelelnek, mint ők. Pontosan ezért szükséges fellépni ellenük, hátrányba hozni, kiszorítani őket, mert megjelenésükkel, fellépésükkel, tevékenységükkel egyértelmúvé tették azt, hogy - Baumol (1982) terminológiája szerint - az aktuális status quo jó eséllyel eredményesen támadható, megváltoztatható. Geletkanycz (1997) szerint a mindenkori status quo irányába való elkötelezettség - szinte genetikailag kódolva - a társadalmi normákban, értékekben gyökerezik. Az azonban már egyáltalán nem magától értetődő, hogy az újonnan létrejövő magasabb minőséget vagy az azt képviselő szereplőket erőfölénnyel visszaélve olyan mértékü hátrányba kell hozni, amely már negatív szelekciónak felel meg. Legyenek fokozottan szigorúak a szelekciós követelmények az új dolgok tekintetében, de a fejlődés lehetséges eszközeit, letéteményeseit nem kívánatos szisztematikusan leküzdhetetlen hátrányba hozni (Geletkanycz 1997).

Olson (2008) szerint elsöprő erejű intézményi változásoknak kell előkészíteniük a terepet a radikális gazdasági fejlődéshez vagy átalakuláshoz. Ehhez azonban az szükséges, hogy a status quo fenntartásában érdekelt, nagy alkuerővel és érdekérvényesítő képességgel rendelkező szereplői kör e tekintetben jelentősen meggyengüljön. Ehhez a szelekció során már rövid távon érdemi hátrányba kell kerülniük. 
Az intézményi, politikai változások révén a fennálló szelekciós követelményeknek egyébként a legmagasabb szinten megfelelő szereplők elveszíthetik az erős alkupozícióikat, érdekérvényesítő képességüket a kormányzati hatalom tekintetében. Amennyiben a gazdaságban a szelekciós követelmények nem változtak meg, úgy a piaci mechanizmusok - így erőfölénnyel való élés vagy visszaélés - révén nem igazán lehet a követelményeknek leginkább megfelelő szereplőket negatív szelekció révén meggyengíteni. A kormányzat azonban hatékonyabban képes a hatalmával visszaélve beindítani a negatív szelekció folyamatát. Azért visszaélve, mert bár formálisan jogszerűnek tűnhetnek az ilyen irányú intézkedések, de nyilvánvaló ellentétben állnak a kormányzott csoport gazdasági és egyéb érdekeivel. Ez történt a II. világháborút követően hazánkban is, amikor az akkori rendszerváltás érdekében a kulákokat kitelepítették, s kiterjedt államosítások zajlottak (Glatz 1997). Kezdetben a legsikeresebb, legnagyobb falusi gazdálkodók, illetve vállalatok voltak a célpontok, később a megmaradtak közül a relatíve legsikeresebbek, legnagyobbak. Mindez tartós hátrányt eredményezett a hazai gazdaság fejlődésében.

\section{Konklúziók}

Viszonylag sok esetben vannak olyan szelekciós kritériumok a mindennapokban, melyek érvényesülése a gazdaságban nyilvánvalóan nem támogatja a fejlődést még rövid távon sem. Ugyanakkor a kontraszelekció jelensége valójában nagyon ritkán üti csak fel a fejét, hiszen annak egyformán előfeltétele a nagymértékű rejtett információtömeg, illetve az érintettek teljes jóhiszeműsége. A negatív szelekció ehhez képest szükségszerűbben gyakoribb eset. A releváns információk ilyenkor a felek rendelkezésére állnak. Ugyanakkor tudatosan visszaél erőfölényével, illetve hatalmával az azzal rendelkező egyén vagy csoport. Méghozzá pontosan azok hátrányára, akik aktuálisan leginkább megfelelnek a fennálló szelekciós követelményeknek, ennek ellenére a megfelelő alkupozíció, illetve érdekérvényesítő képesség hiányában kiszolgáltatottak. A birtokolt erőfölénnyel, hatalommal azonban „rendeltetésszerűen” is lehet élni, amely révén pozitív - a fejlődést jó eséllyel elősegítő - szelekciót lehet megvalósítani (ennek összefoglalását lásd a 2. táblázatban). 


\begin{tabular}{|c|c|c|}
\hline Megnevezés & Visszaélés az erőfölénnyel & Példa az erőfölénnyel való élésre \\
\hline $\begin{array}{l}\text { Minőségtől független, egyenlő } \\
\text { elbánás }\end{array}$ & $\begin{array}{l}\text { Legjobb input-oldali szereplők } \\
\text { kivéreztetése; kollektív büntetés, } \\
\text { kollektív jutalom }\end{array}$ & $\begin{array}{l}\text { Minőség szerinti differenciált } \\
\text { ellenérték-meghatározás, } \\
\text { gyengébb minőséget képviselő } \\
\text { szereplők fejlődésre ösztönzése, } \\
\text { kényszerítése }\end{array}$ \\
\hline $\begin{array}{l}\text { Eseti és kollektív puha } \\
\text { költségvetési korlát }\end{array}$ & $\begin{array}{l}\text { A legjobban gazdálkodók } \\
\text { hátrányba hozása, alternatív } \\
\text { költségeik utólagos drasztikus } \\
\text { megnövelése }\end{array}$ & $\begin{array}{l}\text { A gyengébb szereplők kimentése } \\
\text { mellett a segítséget nem igénylők } \\
\text { teljes kompenzálását is } \\
\text { lényegesen meghaladó arányos } \\
\text { prémium biztosítása }\end{array}$ \\
\hline Korrupciós rejtett tevékenység & $\begin{array}{l}\text { A legjobb, rejtett tevékenységet } \\
\text { nem folytató érintettek } \\
\text { kiszorítása }\end{array}$ & $\begin{array}{l}\text { Az egyéni és a csoportérdekek } \\
\text { összehangolását és magas szintű } \\
\text { egyéni érdekeltséget biztosító } \\
\text { szervezet létrehozása }\end{array}$ \\
\hline $\begin{array}{l}\text { Monopólium diszkriminatív } \\
\text { fellépése }\end{array}$ & $\begin{array}{l}\text { Diszkrimináció a legjobb ügyfelek } \\
\text { kárára }\end{array}$ & $\begin{array}{l}\text { Innovációk a vevők számára } \\
\text { vonzóbb termékért vagy } \\
\text { költségcsökkentésért; a vevők } \\
\text { tudásának növelése }\end{array}$ \\
\hline $\begin{array}{l}\text { Magasabb minőség } \\
\text { visszaszorítása a status quo } \\
\text { fenntartása, vagy } \\
\text { megváltoztatása érdekében }\end{array}$ & $\begin{array}{l}\text { A legjobb minőségű érintettek } \\
\text { háttérbe szorítása }\end{array}$ & $\begin{array}{l}\text { Folyamatos tervezés, folyamatos } \\
\text { tanulás és alkalmazkodás iránti } \\
\text { ösztönzés, kikényszerítés }\end{array}$ \\
\hline
\end{tabular}

Akerlof és Klenow (2009:323) szerint a korrupció észlelése - más negatív szelekcióhoz hasonlóan - jelzés arra vonatkozóan, hogy a csoport fejlődése szempontjából „rossz emberek” férkőztek a rendszerbe. Ezek a „rossz emberek” valójában érdekidegen testnek számítanak, a csoportérdekekkel nem összeegyeztethető külső érdekeket szolgálnak ki álcsoporttagként. Bár látszólag csoporttagok, valójában éppen ellenkezőleg, ilyen módon a jelenlétük, potyautas-tevékenységük negatív externáliát okoz egyes érdekelt csoportoknak, s ilyen módon megvalósítja valamennyi Stiglitz és Greenwald (2016:188-190) által megjelölt - a 2. fejezetpontban már hivatkozott - szelekciós problémát eredményező okot:

- Ezeknek az erőfölényükkel, hatalmukkal visszaélő egyéneknek a siker egyetlen kritériuma a profit;

- Tervezési időhorizontjuk potyautasként rövid;

- Tevékenységük eredményeképp a szelekciós követelményeknek leginkább megfelelők szorulnak háttérbe, iktatódnak ki a legrövidebb idő alatt;

- A rendre negatív externáliát eredményező múködésük által megszerzett irracionális bőségük hosszú távon is szelekciós előnyt biztosít számukra. 
A fejlett piacgazdaságokat tekintve az élenjáró országokat nem az különbözteti meg a többi országtól, hogy ott nincs jelen széleskörűen a piacokon erőfölény, vagy nem koncentrálódik a hatalom olyan mértékben. A lényegi különbség abban áll, hogy az élenjáró országokban döntően élnek, s nem visszaélnek az erőfölénnyel és a hatalommal.

\section{Felhasznált irodalom}

Ajzen, I. (1991): The Theory of Planned Behaviour. Organizational Behaviour and Human Decision Processes, 50(2): 179-211. https://doi.org/10.1016/0749-5978(91)90020-T

Akerlof, G.A. (1970): The Market for "Lemons": Quality Uncertainty and the Market Mechanism. The Quarterly Journal of Economics, 84(3): 488-500. https://doi. org/10.2307/1879431

Akerlof, G.A. - Klenow, J. (2009): Why Doesn't Capitalism Flow to Poor Countries? Comments and Discussion. Brookings Papers on Economic Activity, vol. 2009. pp. 322-332. https:// doi.org/10.1353/eca.0.0061

Aoki, M. (1984): The co-operative game theory of the firm. Oxford, Clarendon Press, 229. p.

Arrow, K.J. (1979): Információ és gazdasági viselkedés. 367-382. p. In: Arrow K.J. (1979): Egyensúly és döntés - válogatott tanulmányok. Budapest, KJK, 411. p

Avilés, L. (2002): Solving the freeloaders paradox: Genetic associations and frequency dependent selection in the evolution of cooperation among nonrelatives. Proceedings of the National Academy of Sciences 99, pp. 14268-14273. https://doi.org/10.1073/ pnas. 212408299

Bardhan, P. (1997): Corruption and Development: A Review of Issues. Journal of Economic Literature, 35(3): 1320-1346.

Barry, B.J.L. (1961): City Size Distributions and Economic Development. Economic Development and Cultural Change, 9(4/1): 573-588. https://doi.org/10.1086/449923

Baumol, W.J. (1982): Contestable Markets: An Uprising in the Theory of Industry Structure. The American Economic Review, 70(1): 1-15.

Bester, H. (1985): Screening vs. Rationing in Credit Markets with Imperfect Information. The American Economic Review, 75(4): 850-855.

Beinhocker, E.D. (2006): The Origin of Wealth: Evolution, Complexity, and the Radical Remaking of Economics. Harvard Business School Press, Boston, Massachusetts, 526. p. 
Bergh, J.C.J.M. van den - M. Stagl, S. (2003): Coevolution of economic behaviour and institutions: towards a theory of institutional change. Journal of Evolutionary Economics, 13(3): 289-317. https://doi.org/10.1007/s00191-003-0158-8

Bergh, J.C.J.M. van den - Gowdy, J.M. (2009): A Group Selection Perspective on Economic Behavior, Institutions and Organizations. Journal of Economic Behavior and Organization, 72(1): 1-20. https://doi.org/10.1016/j.jebo.2009.04.017

Besanko, D. - Donnenfeld, S. - White, L.J. (1987): Monopoly and Quality Distortion: Effects and Remedies. The Quarterly Journal of Economics, 102(4): 743-768. https://doi. org/10.2307/1884279

Clarkson, M.B.E. (1995): A Stakeholder Framework for Analyzing and Evaluating Corporate Social Performance. The Academy of Management Review, 20(1): 92-117. https://doi. org/10.5465/amr.1995.9503271994

Deng, K.G. (2003): Development and Its Deadlock in Imperial China, 221 B.C. -1840 A.D. Economic Development and Culture Change, 51(2): 479-522. https://doi. $\operatorname{org} / 10.1086 / 345732$

Diamond, J. (2009): Összeomlás: tanulságok a társadalmak továbbéléséhez. Typotex Kiadó, Budapest, 580. 0 .

Dong, D. - Saha, A. (1998): He came, he saw, (and): he waited: an empirical analysis of inertia in technology adoption. Applied Economics, 30(7): 893-905. https://doi. org/10.1080/000368498325327

Dosi, G. - Nelson, R.R. (1994): An introduction to evolutionary theories in economics. Journal of Evolutionary Economics, 4(3): 153-172. https://doi.org/10.1007/BF01236366

Eisenhardt, K.M. (1989): Agency theory: An assessment and review. Academy of Management Review, 14(1): 57-74. https://doi.org/10.5465/amr.1989.4279003

Forgács Iván (2013): Miért nincs (soha) elég pénz az egészségügyre? Interdiszciplináris Magyar Egészségügy, 12(7): 5-9.

Freeman, R.E. (1984): Strategic Management - A Stakeholder Approach. London, Pitman Books, 292. p.

Freeman, R.E. - Liedtka, J. (1997): Stakeholder Capitalism and the Value Chain. European Management Journal, 15(3): 286-296. https://doi.org/10.1016/S0263-2373(97)00008-X

Friedman, M. (2007): The Methodology of Positive Economics. 145-178. p. In: Hausman, D.M. (szerk.): The Philosophy of Economics - an Anthology. Cambridge, Cambridge University Press, 536. p. https://doi.org/10.1017/CBO9780511819025.010 
Geletkanycz, M. A. (1997): The Salience of 'Culture's Consequences': The Effects of Cultural Values on Top Executive Commitment to the Status Quo. Strategic Management Journal, 18(8): 615-634. https://doi.org/10.1002/(SICI)1097-0266(199709)18:8<615::AIDSMJ889>3.0.CO;2-I

Glatz Ferenc (1997): Kollektiv felelösség - kollektiv öngyilkosság. Többségek - kisebbségek együttélése. História, 1997(2): 8-10.

Graaf, G. de - Huberts, L.W.J.C. (2008): Portraying the Nature of Corruption Using an Explorative Case Study Design. Public Administration Review, 68(4): 640-653. https:// doi.org/10.1111/j.1540-6210.2008.00904.x

Greif, A. (2006): Institutions and the Path to the Modern Economy: Lessons of Medieval Trade. Cambridge, Cambridge University Press, 526. p. https://doi.org/10.1017/ CBO9780511791307

Guriev, S. (2004): Red tape and corruption. Journal of Development Economics, 73(2): 489504. https://doi.org/10.1016/j.jdeveco.2003.06.001

Hagemann, H. (2008): Schumpeter on development. 225-242. p. In: Shionoya, Y. - Nishizawa, T. (szerk.): Marshall and Schumpeter on Evolution - Economic Sociology of Capitalist Development. Northampton - Cheltenham, Edward Elgar, 285. p.

Hámori Balázs (2002): Érzelem-gazdaságtan - A közgazdasági elemzés kiterjesztése. Budapest, Kossuth Kiadó, 224. p.

Hardin, G. (1968): The Tragedy of Commons. Science, 162(3859): 1243-1248. https://doi. org/10.1126/science.162.3859.1243

Harford, T. (2011): Az alkalmazkodás logikája: Miért kezdődik a siker mindig kudarccal? HVG Kiadó, Budapest, 349. p.

Heckathorn, D.D. (1993): Collective Action and Group Heterogeneity: Voluntary Provision Versus Selective Incentives. American Sociological Review, 58(3): 329-350. https://doi. org/10.2307/2095904

Heidenheimer, A.J. - Johnston, M. (2011): Political Corruptions: Concepts and Context. Transaction Publishers, New Brunswick, New Jersey, 850 p.

Hillman, A.L. - Katz, E. (1984): Risk-Averse Rent Seekers and the Social Cost of Monopoly Power. The Economic Journal, 94(373): 104-110. https://doi.org/10.2307/2232219

Hirschman, A.O. (1995): Kivonulás, tiltakozás, hüség. Osiris Kiadó, Budapest, 170. p.

Huntington, S.P. (1968): Political Order in Changing Societies. Yale University Press, New Haven, 500. p. 
Kegan, R. - Lahey, L.L. (2017): Immunis a változásra - Hogyan ismerjük fel és győzzük le önmagunk és csapatunk ellenállását? HVG Kiadó, Budapest, 382. p.

Kornai János (1993): A szocialista rendszer. Budapest, HVG Kiadó, 670. p.

Kornai János (1997): Pénzügyi fegyelem és puha költségvetési korlát. Közgazdasági Szemle, 53(11): 940-953.

Kornai János (2008): A puha költségvetési korlát szindrómája a kórházi szektorban. Közgazdasági Szemle, 55(12): 1037-1056.

Kornai János (2010): Innováció és dinamizmus. Közgazdasági Szemle, 57(1): 1-36.

Kornai, J. - Maskin, E. - Roland, G. (2004): A puha költségvetési korlát I. Közgazdasági Szemle, 60(7-8): 608-624.

Kotosz Balázs (2002): Evolúciós megközelítés a közgazdaságtanban, avagy modellezés versus racionális várakozások. In: Beszteri Béla - Lévai Imre (szerk.): Régiók Európája. Tanulmánykötet, Budapest Fórum, Budapest, pp. 111-118.

Laffont, J.J. - Tirole, J. (1988): The Dynamics of Incentive Contracts. Econometrica, 56(5): 1153-1175. https://doi.org/10.2307/1911362

Lambsdorff, J. G. (2002): Corruption and rent-seeking. Public Choice, 113(1-2): 97-125. https://doi.org/10.1023/A:1020320327526

Leff, N.H. (1964): Economic Development Through Bureaucratic Corruption. American Behavioral Scientist, 8(3): 8-14. https://doi.org/10.1177/000276426400800303

Lentner Csaba (2014): A magyar önkormányzatok adósságkonszolidációja. Pénzügyi Szemle, 59(3): 330-344.

Major Iván (2014): Ha elfogy a bizalom... Kialakitható-e optimális mechanizmus kétoldalú aszimmetrikus információ esetén? Közgazdasági Szemle, 61(2): 148-165.

Méon, P.G. - Sekkat, K. (2005): Does corruption grease or sand the wheels of growth? Public Choice, 122(1): 69-97. https://doi.org/10.1007/s11127-005-3988-0

Milgrom, P. (1987): Adverse Selection without hidden information. Working Paper No. 8742, University of California, Berkeley.

Mitchell, R.K. - Agle, B.R. - Wood, D.J. (1997): Toward a Theory of Stakeholder Identification and Salience: Defining the Principle of Who and What Really Counts. The Academy of Management Review, 22(4): 853-886. https://doi.org/10.5465/amr.1997.9711022105

Mo, P.H. (2001): Corruption and Economic Growth. Journal of Comparative Economics, 29(1): 66-79. https://doi.org/10.1006/jcec.2000.1703 
Mokyr, J. (2004): A gazdaság gépezete. Nemzeti Tankönyvkiadó, Budapest.

Mussa, M. - Rosen, S. (1978): Monopoly and Product Quality. Journal of Economic Theory, 18(2): 301-317. https://doi.org/10.1016/0022-0531(78)90085-6

Narloch, U. - Pascual, U. - Drucker, A.G. (2012): Collective Action Dynamics under External Rewards: Experimental Insights from Andean Farming Communities. World Development, 40(10): 2096-2107. https://doi.org/10.1016/j.worlddev.2012.03.014

Nazaretyan, A.P. (2003): Power and Wisdom: Toward a History of Social Behavior. Journal of the Theory of Social Behaviour, 33(4): 405-425. https://doi.org/10.1046/j.14685914.2003.00224.x

Nelson, R.R. (1995): Recent Evolutionary Theorizing About Economic Change. Journal of Economic Literature, 33(1): 48-90.

Nelson, R.R. - Winter, S.G. (1982): An Evolutionary Theory of Economics Change. London, The Belknap Press of Harvard University Press, 454. p.

Olson, M. (1965): The Logic of Collective Action. Harvard University Press, Cambridge.

Olson, M. (2008): The rise and decline of nations: Economic growth, stagflation, and social rigidities. Yale University Press, New Haven.

Pindyck, R.S. (1985): The Measurement of Monopoly Power in Dynamic Markets. The Journal of Law \& Economics, 28(1): 193-222. https://doi.org/10.1086/467080

Polignac, F. (1995): Cults, Territory, and the Origins of The Greek City State. Chicago - London, University Chicago Press, 204. p.

Rey, P. - Salanié, B. (1996): On the Value of Commitment with Asymmetric Information. Econometrica, 64(6): 1395-1414. https://doi.org/10.2307/2171836

Riley, J.G. (1989): Signalling. In: Eatwell, J. - Milgate, M. - Newman, P. (eds): Allocation, Information and Markets. The New Palgrave. Palgrave Macmillan, London.

Rothschild, M. - Stiglitz, J. (1976): Equilibrium in Competitive Insurance Markets: An Essay on the Economics of Imperfect Information. The Quarterly Journal of Economics, 90(4): 629-649. https://doi.org/10.2307/1885326

Samuelson, W. - Zeckhauser, R. (1988): Status Quo Bias in Decision Making. Journal of Risk and Uncertainty, 1(1): 7-59. https://doi.org/10.1007/BF00055564

Sandlin, J.A. - Mclaren, P. (2010): Exploring Consumption's Pedagogy and Envisioning a Critical Pedagogy of Consumption - Living and Learning in the Shadow of the "Shopocalypse". 1-20. p. In: Sandlin, J.A. - Mclaren, P. (szerk.): Critical Pedagogies of Consumption - Living and Learning in the Shadow of the "Shopocalypse". New York London, Routledge, 304. p. 
Schumpeter, J.A. (1980): A gazdasági fejlődés elmélete. Budapest, Közgazdasági és Jogi Könyvkiadó, 320. p.

Schumpeter, J.A. (1942): Capitalism, Socialism, and Democracy. New York, Harper and Brothers, $431 \mathrm{p}$.

Shionoya, Y. (2008): Schumpeter and evolution: an ontological exploration. 15-35. p. In: Shionoya, Y. - Nishizawa, T. (szerk.): Marshall and Schumpeter on Evolution - Economic Sociology of Capitalist Development. Northampton - Cheltenham, Edward Elgar, 285. p.

Solow, R.M. (1979): Another possible source of wage stickiness. Journal of Macroeconomics, 1(1): 79-82. https://doi.org/10.1016/0164-0704(79)90022-3

Spence, M.A. (1973): Job Market Signaling. The Quarterly Journal of Economics, 87(3): 355-374. https://doi.org/10.2307/1882010

Stiglitz, J.E. (1975): The Theory of "Screening," Education, and the Distribution of Income. The American Economic Review, 65(3): 283-300.

Stiglitz, J.E. (1986): The economics of public sector. New York, W. W. Norton \& Company, $599 \mathrm{p}$.

Stiglitz, J.E. - Greenwald, B.C. (2016): A tanuló társadalom megteremtése - A növekedés, a fejlődés és a társadalmi haladás kérdéseinek új megközelítése. Napvilág Kiadó, Budapest, $679 \mathrm{p}$.

Sylvander, B. - Belletti, G. - Marescotti, A. - Thévenod-Mottet, E. (2006): Establishing a quality convention, certifying and promoting the quality of animal products: the case of beef. 61-82. p. In: Rubino, R. - Sepe, L. - Dimitriadou, A. - Gibon, A. (szerk.): Livestock farming systems - product quality on local resources leading to improved sustainability. (EAAP Scientific Series), vol. 118, Benevento, Italy, EAAP Publication, 410. p.

Széchenyi István (1830): Hitel. In: Széchenyi István (1930): Gróf Széchenyi István Válogatott munkái (1930). Budapest, Lampel Róbert Könyvkereskedés, 808. p.

Tirole, J. (2016): From Bottom of the Barrel to Cream of the Crop: Sequential Screening with Positive Selection. Econometrica, 84(4): 1291-1343. https://doi.org/10.3982/ECTA12961

Utton, M.A. (2003): Market Dominance and Antitrust Policy. Edward Elgar, Cheltenham, UK, 342. p. https://doi.org/10.4337/9781843767480

Veblen, T. (1899): The Theory of the Leisure Class. Macmillan, New York - (2007): reprint, New York, Oxford University Press, 304 p.

Veblen, T. (1972): A dologtalan osztály elmélete. Budapest, Közgazdasági és Jogi Kiadó, 400 p. 
Vickers, J. (2005): Abuse of Market Power. The Economic Journal, 115(504): F244-F261. https://doi.org/10.1111/j.1468-0297.2005.01004.x

Vigneault, M. (2005): Intergovernmental Fiscal Relations and the Soft Budget Constraint Problem. IIGR Working Paper 2, Queen's University, Kingston, Ontario, Canada, 30. p.

Vincze János (1991a): Fejezetek az információ közgazdaságtanából - II. A kontraszelekció. Közgazdasági Szemle, 38(3): 289-306.

Vincze János (1991b): Fejezetek az információ közgazdaságtanából - III. Morális kockázat és kontraszelekció az időben. Közgazdasági Szemle, 38(4): 435-445.

Willer, R. (2009): Groups Reward Individual Sacrifice: The Status Solution to the Collective Action Problem. American Sociological Review, 74(1): 23-43. https://doi. org/10.1177/000312240907400102

Williamson, O.E. (2000): The New Institutional Economics: Taking Stock, Looking Ahead. Journal of Economic Literature, 38 (3): 595-613. https://doi.org/10.1257/jel.38.3.595 